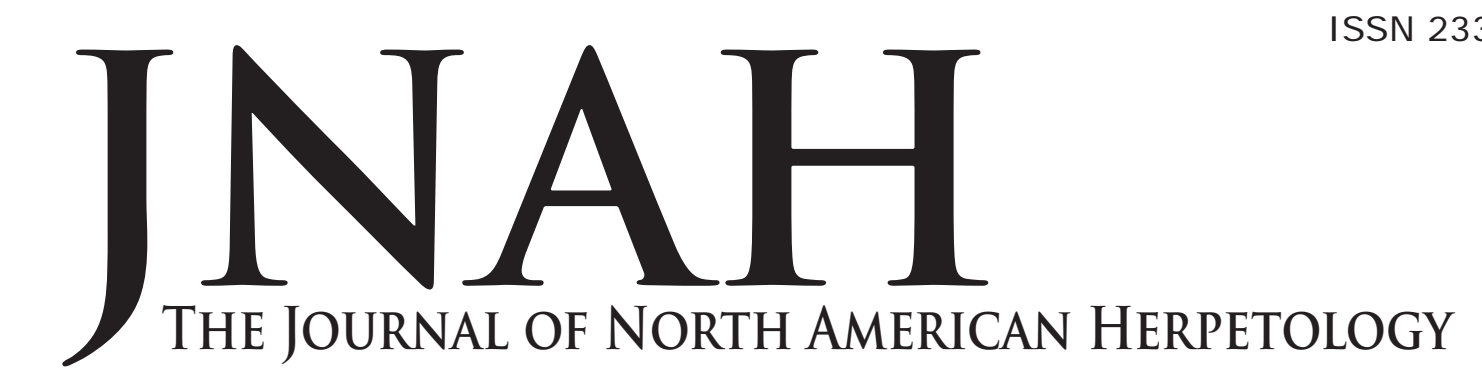

Volume 2015(1): 34-42

1 May 2015

jnah.cnah.org

\title{
WOODLAND POND SALAMANDER ABUNDANCE IN RELATION TO FOREST MANAGEMENT AND ENVIRONMENTAL CONDITIONS IN NORTHERN WISCONSIN
}

\author{
DEAHN M. DONNER ${ }^{1,5}$, CHRISTINE A. RIBIC ${ }^{2}$, ALBERT J. BECK ${ }^{3}$, DALE HIGGINS ${ }^{4}$, \\ DAN EKLUND ${ }^{4}$, AND SUSAN REI NECKE ${ }^{4}$ \\ ${ }^{1}$ U.S. Forest Service, Northern Research Station, Institute for Applied Ecosystem Studies, \\ Rhinelander, WI 54501; 715-362-1146; \\ ${ }^{2}$ U.S. Geological Survey, Wisconsin Cooperative Wildlife Research Unit, Department of Forest \\ and Wildlife Ecology, University of Wisconsin, Madison, WI 53706 \\ ${ }^{3}$ Department of Forest and Wildlife Ecology, University of Wisconsin, Madison, WI 53706 \\ ${ }^{4}$ U.S. Forest Service, Chequamegon-Nicolet National Forest, Parks Falls, WI 54552 \\ ${ }^{5}$ Corresponding author. ddonnerwright@fs.fed.us
}

\begin{abstract}
Woodland ponds are important landscape features that help sustain populations of amphibians that require this aquatic habitat for successful reproduction. Species abundance patterns often reflect site-specific differences in hydrology, physical characteristics, and surrounding vegetation. Large-scale processes such as changing land cover and environmental conditions are other potential drivers influencing amphibian populations in the Upper Midwest, but little information exists on the combined effects of these factors. We used Blue-spotted (Ambystoma laterale Hallowell) and Spotted Salamander (A. maculatum Shaw) monitoring data collected at the same woodland ponds thirteen years apart to determine if changing environmental conditions and vegetation cover in surrounding landscapes influenced salamander movement phenology and abundance. Four woodland ponds in northern Wisconsin were sampled for salamanders in April 1992-1994 and 2005-2007. While Bluespotted Salamanders were more abundant than Spotted Salamanders in all ponds, there was no change in the numbers of either species over the years. However, peak numbers of Blue-spotted Salamanders occurred 11.7 days earlier (range: 9-14 days) in the 2000s compared to the 1990s; Spotted Salamanders occurred 9.5 days earlier (range: 3 - 13 days). Air and water temperatures (April 13- 24) increased, on average, $4.8^{\circ} \mathrm{C}$ and $3.7^{\circ} \mathrm{C}$, respectively, between the decades regardless of pond. There were no discernible changes in canopy openness in surrounding forests between decades that would have warmed the water sooner (i.e., more light penetration). Our finding that salamander breeding phenology can vary by roughly 10 days in Wisconsin contributes to growing evidence that amphibian populations have responded to changing climate conditions by shifting life-cycle events. Managers can use this information to adjust monitoring programs and forest management activities in the surrounding landscape to avoid vulnerable amphibian movement periods. Considering direct and indirect stressors such as changing habitat and environmental conditions simultaneously to better understand trends in space and time can help improve monitoring programs for this taxa, which is at major risk of continued declines.
\end{abstract}

INTRODUCTION

Amphibian populations are experiencing widespread and severe declines throughout North America with salamander populations declining at a faster rate than frogs (Houlahan et al., 2000; Adams et al., 2013). Many amphibians in forested regions rely on woodland ponds for successful reproduction (Colburn, 2004). Species richness and abundance in these ponds depends on hydrology, pond physical characteristics, and the landscape matrix around each pond (e.g., Brooks and Hayashi, 2002;
Burn and Griffin, 2005; Skidds and Golet, 2005; Van Buskirk, 2005). A pond's hydroperiod (i.e., duration of flooding) is determined by temperature and local precipitation that influence the frequency and timing of flooding, evapotranspiration, and by the pond's physical attributes that influence how much water enters and stays in the system (e.g., water depth and volume; see Colburn, 2004). Because hydroperiod varies widely across years, it is difficult to separate whether population fluctuations are a result of broad-scale environmental processes af- 
Table 1. Peak mean salamander numbers per trap night (maximum 3-day running mean) and attributes of 4 ponds in the Chequamegon-Nicolet National Forest, Wisconsin, 1992-1994 and 2005-2007. Mean water depth and surface area for Pond 23 for 1990s data is estimated (see text for details).

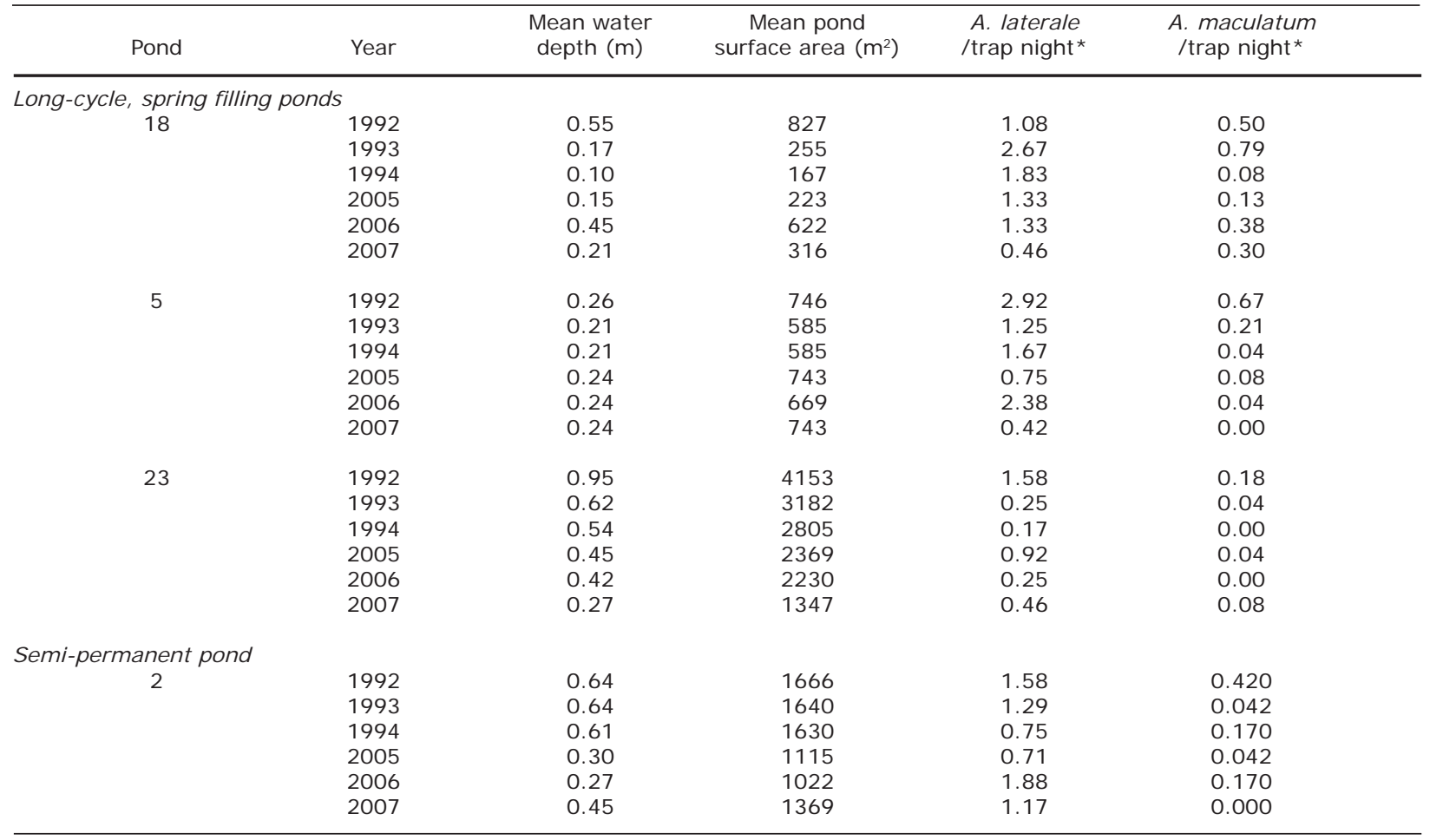

* Maximum 3-day running mean

fecting hydrology of the seasonal breeding ponds, or whether populations are responding to local-scale vegetation changes in the surrounding landscapes (Carey and Alexander, 2003; Baldwin et al., 2006; Todd et al., 2011).

Many land management plans provide standards and guidelines to protect or restore woodland ponds (e.g., Holaday and Wagner, 2010) and use monitoring of species requiring these ponds as a proxy for evaluating habitat condition and whether plan objectives have been met (e.g., populations have not declined due to reduced quantity or quality of the habitat). Mole salamanders are one group of species dependent on woodland ponds for breeding that are often used for monitoring (Colburn, 2004). These forest-dependent species (Petranka, 1998) also rely on the surrounding upland forest to forage and overwinter. Thus, this bi-phasic life history strategy makes woodland salamanders good candidates for evaluating how habitat management activities in the surrounding landscapes may impact populations using woodland ponds as well as evaluating the condition of woodland pond habitat. These traits also make salamanders susceptible to regional climate change (Foden, 2013) making it important to monitor populations of this taxa to help mitigate local threats to ensure long-term viability of populations.

However, monitoring activities are complicated for these species because of the variability in timing of movement events (i.e., phenology) in response to local weather conditions (Brooks, 2004; Hocking et al., 2008; Pechmann et al., 1989). Amphibian populations are known to be highly variable through space and time (Meyer et al., 1998). In addition, abundance estimates within ponds are confounded if environmental conditions change in concert with events in the surrounding landscape that could affect survival of individuals as they move to the ponds (Semlitsch, 2002). Thus, results from a monitoring program must consider higher-level environmental conditions as well as changing local habitat conditions in the surrounding landscape simultaneously to better understand the mechanisms driving local population trends (Gardner et al., 2007)

Mole salamanders use woodland ponds that are deep enough to sustain water levels throughout their aquatic life-stage (i.e., longer hydroperiod) but remain fishless (Colburn, 2004). In the Upper Great Lakes region, Ambystoma laterale Hallowell (Blue-spotted) Salamanders and A. maculatum Shaw (Spotted) Salamanders are the primary mole salamanders using woodland ponds for breeding. The timing of movement to the breeding ponds is determined by precipitation and temperature factors (e.g., Baldauf 1952; Madison, 1997; Sexton, 1990; Timm et al., 2007; Hocking et al., 2008). A. maculatum typically arrive in woodland ponds a few days later than A. laterale (Harding, 2000). In the Great Lakes region, adults migrate to the ponds in early spring (typically late March to mid-April when the ice is melting and ground is thawing), deposit eggs, and then disperse into the surrounding landscape where they spend the majority of their life cycle (Stebbins and Cohen, 1995).

Disturbances to the surrounding upland vegetation that open the canopy, allowing more light penetration and reducing humidity, can negatively affect survival during movement events due to increased desiccation risk (deMaynadier and Hunter, 1998; Gibbs, 1998; Patrick et al., 2006; Semlitsch et al., 2009). In addition, the degree of changing vegetation cover type amounts may significantly alter foraging and overwintering habitat (e.g., remove plant and organic matter) (e.g., deMaynadier and Hunter, 1995; Baldwin et al., 2006; Veysey et al., 
Table 2. Proportion of cover types within $300 \mathrm{~m}$ of 4 ponds in the Chequamegon-Nicolet National Forest, Wisconsin, surveyed for salamanders $1992-1994$ and 2005-2007. Bold indicates changes in proportion across decades.

\begin{tabular}{|c|c|c|c|c|c|c|c|c|c|c|}
\hline \multirow[b]{2}{*}{ Pond } & \multirow[b]{2}{*}{ Decade } & \multicolumn{9}{|c|}{ Cover type } \\
\hline & & $\begin{array}{c}\text { Upland } \\
\text { hardwood }\end{array}$ & $\begin{array}{l}\text { Upland } \\
\text { confir }\end{array}$ & $\begin{array}{l}\text { Regenerating } \\
\text { upland } \\
\text { confir }\end{array}$ & $\begin{array}{l}\text { Lowland } \\
\text { confir }\end{array}$ & $\begin{array}{l}\text { Upland } \\
\text { deciduous }\end{array}$ & $\begin{array}{l}\text { Regenerating } \\
\text { upland } \\
\text { deciduous }\end{array}$ & $\begin{array}{l}\text { Lowland } \\
\text { shrub }\end{array}$ & $\begin{array}{l}\text { Non- } \\
\text { forest }\end{array}$ & Water \\
\hline \multicolumn{11}{|c|}{ Long-cycle, spring filling ponds } \\
\hline \multirow[t]{2}{*}{18} & $1990 \mathrm{~s}$ & 0.00 & 0.15 & 0.06 & 0.00 & 0.48 & 0.00 & 0.31 & 0.00 & 0.00 \\
\hline & $2000 \mathrm{~s}$ & 0.00 & 0.15 & 0.06 & 0.00 & 0.48 & 0.00 & 0.31 & 0.00 & 0.00 \\
\hline \multirow[t]{2}{*}{5} & $1990 \mathrm{~s}$ & 0.00 & 0.57 & 0.00 & 0.00 & 0.28 & 0.12 & 0.01 & 0.02 & 0.00 \\
\hline & $2000 s$ & 0.00 & 0.05 & 0.14 & 0.00 & 0.40 & 0.38 & 0.01 & 0.02 & 0.00 \\
\hline \multirow[t]{2}{*}{23} & $1990 \mathrm{~s}$ & 0.13 & 0.36 & 0.00 & 0.08 & 0.02 & 0.39 & 0.00 & 0.02 & 0.00 \\
\hline & $2000 \mathrm{~s}$ & 0.13 & $<0.01$ & 0.36 & 0.08 & 0.41 & 0.00 & 0.00 & 0.02 & 0.00 \\
\hline \multicolumn{11}{|c|}{ Semi-permanent pond } \\
\hline \multirow[t]{2}{*}{2} & $1990 \mathrm{~s}$ & 0.23 & 0.01 & 0.00 & 0.36 & 0.18 & 0.02 & 0.00 & 0.17 & 0.03 \\
\hline & $2000 \mathrm{~s}$ & 0.23 & 0.00 & 0.01 & 0.36 & 0.20 & 0.00 & 0.00 & 0.17 & 0.03 \\
\hline
\end{tabular}

2011; Trumbo et al., 2012). To mitigate these effects, many land management plans include specific guidelines to maintain a narrow vegetative border with a 'no harvest or disturbance' buffer that also provides water quality and erosion control (Semlitsch, 1998). Many argue, however, that narrow buffers are inadequate given the majority of adult salamanders may winter greater than $100 \mathrm{~m}$ from breeding ponds (e.g., Faccio, 2003; Semlitsch and Bodie, 2003; Regosin et al., 2005; Patrick et al., 2006).

Much debate also exists on how long harvesting activities may affect salamander populations due to the differences in intensity and frequencies of alternative silvicultural treatments (Patrick et al., 2006). Most studies measure the short-term impact of forest management activities immediately following a harvest that decreases canopy cover significantly (e.g., clear cut), but in a forested system that is treated through partial harvesting, this impact may be transient due to succession (Morris and Maret, 2007; Semlitsch et al., 2009). Little information exists on how salamander populations respond to local forest management activities over long enough time periods that encompass both broad-scale environmental changes, which may affect hydroperiod and salamander movement patterns, and vegetative succession that may influence overall abundances. To our knowledge, there is no information quantifying the temporal variability in salamander movement to ponds in the Upper Great Lakes in tandem with surrounding vegetation changes. More information is needed on how these factors that operate at different scales influence populations of woodland pond-dependent species, especially when changing climate conditions are expected to increase frequency of droughts thereby shortening the hydroperiod for these aquatic systems (Brook, 2009; Visser and Both, 2005).

We used salamander monitoring data collected at the same woodland ponds thirteen years apart to determine if changing ( 1 ) environmental conditions (i.e, air and water temperatures and precipitation as reflected in water depth and surface area of the ponds) and (2) vegetation cover in surrounding landscapes influenced salamander phenology and abundance, respectively. Both aspects are important to better understand and balance direct (e.g., structural habitat change) and indirect (e.g., climate change) stressors to amphibian populations for long-term conservation of these species and their habitat (Gardner et al., 2005).

\section{MATERI ALS AND METHODS}

Woodland pond characteristics - Four woodland ponds in the Medford-Park Falls District of the ChequamegonNicolet National Forest (Price County, Wisconsin) were sampled for A. laterale and A. maculatum in 1992-1994 and 2005-2007 (Figure 1). These ponds are part of an established state frog and toad survey where the hydrology of the sites is monitored annually. The 4 woodland ponds have different vegetation cover due to different silvicultural treatments done around the ponds and have different hydrologic conditions.

Using Colburn's (2004) hydrologic continuum, which incorporates timing and duration of flooding, we classified three ponds (Ponds 18, 5, 23) as long-cycle, spring-filling ponds. By definition, these ponds gain more than $50 \%$ of their volume in spring through precipitation, storm runoff and snowmelt; ponds remain flooded 5-8 months. These ponds can remain flooded for an entire year during wet conditions, but are not continuously flooded more than once in five years. Ponds remain flooded long enough to support salamander breeding, and the sediments remain saturated at or near the surface after the standing water has disappeared. As part of the state-wide annual frog and toad survey, ponds were visited in late Mayearly June and mid-July each year along with other intermittent visits later in the year to classify hydroperiod and confirm flooding stages (D. Higgins, personal obs.). Water chemistry samples were collected from each pond during spring 1991 and analyzed for alkalinity ( $\mathrm{mg} / \mathrm{l})$, specific conductance $(\mathrm{uS} / \mathrm{cm}$ ) and color (pt-co). Four samples were collected from each pond that year. Results indicated low alkalinity $(<6.5 \mathrm{mg} / \mathrm{l})$, $\mathrm{pH}<6.2$, and specific conductance $(<32 \mathrm{uS} / \mathrm{cm}$ ) suggesting diluted water conditions expected with surface runoff water sources.

Pond 18 (Table 1; Figure 2a) is predominantly an open water pond surrounded by sedges and lowland shrubs. It is an upland, perched pond that receives water from direct precipitation and surface runoff. This shallow pond has greater coarse woody debris than the other ponds in this category (D. Higgins, personal obs.). Pond 5 (Table 1 ; Figure $2 \mathrm{~b}$ ) is a partially shaded $(<25 \%$ ) to open, shallow sedge (Carex spp.) meadow adjoining a larger open bog. Pond 23 (Table 1; Figure 2c) is the largest pool, slightly deeper, and remains predominantly open water. This pond appears to be an exposure of the groundwater table, so water levels drop and rise slowly. It retains water for longer periods of time compared to the other 
Table 3. Date of peak numbers for Ambystoma laterale and A. maculatum caught in 4 ponds in the Chequamegon-Nicolet National Forest, Wisconsin, 19921994 and 2005-2007, and mean air and water temperature at the time of trap checking. Date of peak and mean time of trap check is based on the entire trapping period while mean air and water temperatures are based on April 13-24. Dashes in the A. maculatum column indicate that date of peak could not be calculated because no salamanders were captured.

\begin{tabular}{|c|c|c|c|c|c|c|}
\hline \multirow[b]{2}{*}{ Pond } & \multirow[b]{2}{*}{ Year } & \multicolumn{2}{|c|}{ Date of peak } & \multirow{2}{*}{$\begin{array}{l}\text { Mean observed air } \\
\text { temperature }\left({ }^{\circ} \mathrm{C}\right)\end{array}$} & \multirow{2}{*}{$\begin{array}{l}\text { Mean observed water } \\
\text { temperature }\left({ }^{\circ} \mathrm{C}\right)\end{array}$} & \multirow{2}{*}{$\begin{array}{l}\text { Mean time (CST) } \\
\text { of trap check }\end{array}$} \\
\hline & & A. laterale & A. maculatum & & & \\
\hline \multicolumn{7}{|c|}{ Long-cycle, spring filling ponds } \\
\hline \multirow[t]{6}{*}{18} & 1992 & $4 / 21$ & $4 / 21$ & 6.2 & 5.3 & 0836 \\
\hline & 1993 & $4 / 19$ & $4 / 24$ & 8.6 & 8.3 & 1006 \\
\hline & 1994 & $4 / 26$ & $4 / 25$ & 9.4 & 8.3 & 0948 \\
\hline & 2005 & $4 / 10$ & $4 / 16$ & 12.7 & 11.7 & 1048 \\
\hline & 2006 & $4 / 12$ & $4 / 14$ & 13.4 & 10.3 & 0948 \\
\hline & 2007 & $4 / 02$ & $4 / 01$ & 14.7 & 9.6 & 1130 \\
\hline \multirow[t]{6}{*}{5} & 1992 & $4 / 22$ & $4 / 22$ & 5.2 & 4.1 & 0818 \\
\hline & 1993 & $4 / 28$ & $4 / 26$ & 8.3 & 5.1 & 1048 \\
\hline & 1994 & $4 / 16$ & $4 / 18$ & 9.3 & 5.9 & 0918 \\
\hline & 2005 & $4 / 10$ & $4 / 10$ & 12.1 & 10.5 & 1018 \\
\hline & 2006 & $4 / 11$ & $4 / 12$ & 12.4 & 9.6 & 0930 \\
\hline & 2007 & $4 / 14$ & -- & 15.0 & 7.8 & 1106 \\
\hline \multirow[t]{6}{*}{23} & 1992 & $4 / 22$ & $4 / 20$ & 6.2 & 2.1 & 0848 \\
\hline & 1993 & $4 / 30$ & $4 / 23$ & 9.2 & 7.3 & 1054 \\
\hline & 1994 & $4 / 15$ & -- & 9.0 & 7.4 & 1024 \\
\hline & 2005 & $4 / 11$ & $4 / 16$ & 13.4 & 12.9 & 1130 \\
\hline & 2006 & $4 / 11$ & -- & 13.6 & 13.1 & 1012 \\
\hline & 2007 & $4 / 19$ & $4 / 19$ & 14.9 & 12.6 & 1142 \\
\hline \multicolumn{7}{|c|}{ Semi-permanent pond } \\
\hline \multirow[t]{6}{*}{2} & 1992 & $4 / 22$ & $4 / 23$ & 5.4 & 2.5 & 0806 \\
\hline & 1993 & $4 / 24$ & $4 / 24$ & 6.6 & 4.8 & 1048 \\
\hline & 1994 & $4 / 18$ & $4 / 20$ & 8.8 & 5.8 & 0854 \\
\hline & 2005 & $4 / 10$ & $4 / 25$ & 12.4 & 8.9 & 1012 \\
\hline & 2006 & $4 / 11$ & $4 / 13$ & 12.4 & 9.1 & 0906 \\
\hline & 2007 & $4 / 02$ & -- & 14.3 & 8.3 & 1054 \\
\hline
\end{tabular}

ponds in this category, but it is also the slowest in water recovery from drought conditions. The pond also has submergent vegetation, but little coarse woody debris.

The fourth pond, Pond 2 (Table 1; Figure 2d) is semipermanent and remains continuously flooded, only occasionally drying completely. This pond receives local runoff and overflow water from a neighboring stream during non-drought years. The pond's water chemistry is relatively high alkalinity (18-34 mg/l), and $\mathrm{pH}$ (6.3-6.5) and specific conductance (56-72 uS/ cm) levels are indicative of the water source, which indicates a more permanent status compared to the other ponds. In addition, central mudminnow (Umbra limi) is present in the pond (unpublished data), suggesting overwintering survival and yearlong water flooding conditions.

Landscape classification - We used stand-level forest inventory data maintained by the Chequamegon-Nicolet National Forest (CNNF) to recreate and determine forest age and cover type surrounding each pond for all years within $300 \mathrm{~m}$ buffer from the pond edge. This distance encompasses critical threshold distances found in other studies investigating the influence of forest management on pool-breeding amphibians ( $100 \mathrm{~m}$ for A. maculatum, Homan et al., 2004; 200 m for amphibians, Rittenhouse et al., 2009). Minimum mapping polygon was 4.0 ha. Forest age was calculated for those forest cover types managed through even-aged silvicultural treatments (i.e., clearcut or salvaged cut); age was classified into regenerating (i.e., open canopy) and mature (i.e., closed canopy). Unless noted, all cover types were considered closed canopy conditions. Forest age was calculated for each year of the study based on the year the management stand was silviculturally treated.

We calculated the proportion of cover types within the buffer from the approximate center of each woodland pond using a geographical information system for the two decades: 1990s (1992-1994) and 2000s (20052007). Cover types were classified into 9 categories: (1) upland hardwood comprised of Fraxinus nigra M. (Black Ash)-Ulmus Americana L. (American Elm)-Acer rubrum L. (Red Maple), Acer saccharum M. (Sugar Maple)-Tilia Americana L. (Basswood), Sugar Maple, and mixed upland hardwoods, (2) upland conifer comprised of Pinus banksiana L. (Jack Pine), Pinus resinosa A. (Red Pine), Abies balsamea L. (balsam fir)-Populus tremuloides $M$. (Quaking Aspen)-Betula papyrifera M. (Paper Birch), Pinus strobus L. (Eastern White Pine), Thuja occidentalis L. (Northern White Cedar), Balsam Fir, Picea glauca (Moench) V. (White Spruce)-Balsam Fir, (3) regenerating upland conifer (less than 9 years old for red pine, jack pine, and white spruce), (4) lowland conifer comprised of Picea mariana (Mill.) B. (Black Spruce) and Larix laricina (Du Roi) K. Koch (Tamarack), (5) upland deciduous comprised of quaking aspen, aspen-white spruce-balsam fir, (6) regenerating upland deciduous (less than 5 years old), (7) lowland shrub (Alnus M. spp. (Alder), Salix L. spp. (Willow), (8) nonforest composed of grassland and sedge meadows, bogs and marshes, and (9) open water.

Field Methods - We trapped salamanders using unbaited minnow traps (commercially available, circular steel wire mesh with funnels at each end); 4 (1992) and 8 minnow traps (1993-2007) were installed in each pond immediately following ice breakup and checked daily. Wilson and Pearman (2000) found that using aquatic funnel traps is repeatable, reduces observer bias, lowers habitat disturbance, and produces greater capture success compared to other methods.

Trapping was done primarily in April each year; though 
the exact start of trapping depended on ice breakup and, thus, varied among years. Specific trapping dates were April 16 - May 6 (21 days; 1992), April 8 - May 1 (24 days; 1993), April 8 - 29 (22 days; 1994), April 8 29 ( 22 days; 2005), April 7 - 24 (18 days; 2006), and March 26 - April 26 (32 days; 2007).

Date, time of observation (CST, $24 \mathrm{hr}$ clock), air temperature $\left({ }^{\circ} \mathrm{C}\right)$, water temperature $\left({ }^{\circ} \mathrm{C}\right)$, and total number of salamanders by species were recorded at each check. Water and air temperatures of each pond were taken with a handheld thermometer after taking 1 step (approximately $1 \mathrm{~m}$ ) into the water from the shoreline. Water temperature was taken just below the water surface; only the bulb was placed in the water. Air temperature (approximately $1.5 \mathrm{~m}$ above the water) was taken with a dry bulb to ensure that wet bulb temperatures were not taken.

To determine average water depth and surface area annually, each pond was surveyed in 2011 or 2012 to create a bathymetric map with one-half $(0.15 \mathrm{~m})$ or one-quarter foot $(0.075 \mathrm{~m})$ contours. Each map was referenced to a local benchmark established in April 1992 that consisted of a nail installed in a tree with an assigned local elevation (30.5 m; $100 \mathrm{ft})$. During the salamander trapping periods, pond water levels (i.e., water surface elevation) were recorded to the nearest $0.03 \mathrm{~m}$ using a portable rod and hand level and the permanent benchmarks. Water level measurements were made 3 times at each pond in 1992, twice at Ponds 5 and 23 in 1993 and 1994, and 3 times at Ponds 2 and 18 (in 1993 and 1994). One water level measurement was performed at each pond in 20052007. Each water surface elevation measurement along with the bathymetric contour map of the pond was used to estimate pond area and average water depth. When there were multiple measurements per pond per year, we averaged the water depth and surface area estimates. At Pond 5, open water existed in small portions of the entire wetland while the remaining area was open bog covered by sphagnum moss and Ericaceae species. For this pond, only the open water portion was surveyed. At Pond 23, the benchmark from the 1990s could not be relocated so a new benchmark was established in 2005 and used for all water level readings and the topographic survey in the 2000s. We compared aerial photos from the 1990s with photos and known water levels from the 2000s to relate the 1990s water level measurements to the topographic map and new benchmark. This relation provided an ap-

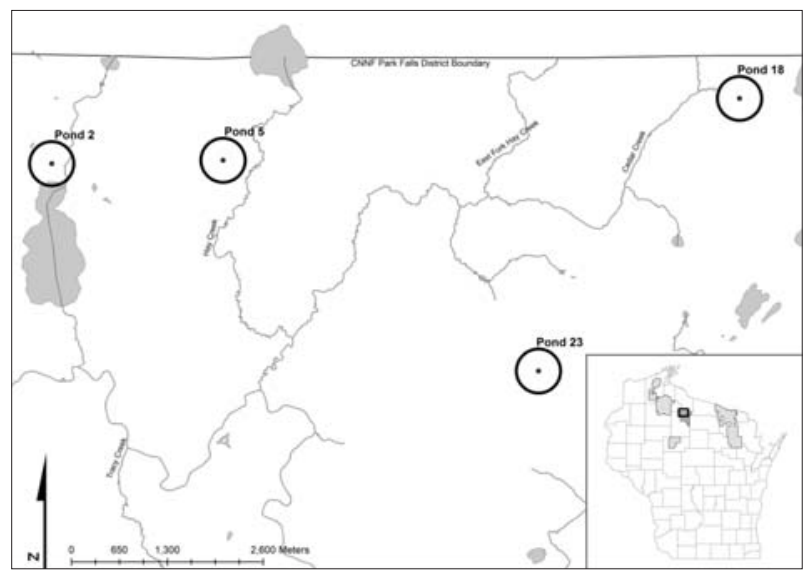

Figure 1. Location of the four woodland ponds on the Medford-Park Falls District of the Chequamegon-Nicolet National Forest, Wisconsin (shaded area in the insert). proximate estimate of water surface area and depth for that pond during the 1990s.

Analysis - The number of salamanders trapped daily was divided by the number of traps to standardize across the years. We used the maximum 3-day running mean over the entire trapping period as an index of the peak number of salamanders/trap night for the ponds each year. The mid-date of the 3-day window was used as the date on which the peak occurred. We compared the mean numbers of $A$. laterale and $A$. maculatum with a paired t-test, which controlled for year and pond.

To compare temperature conditions, we used a common time period (i.e., April 13-24) over which to calculate average air and water temperatures for the ponds each year. To put the air temperatures measured at the ponds in perspective with longer term regional trends, we calculated mean air temperature for April 13-24 for the Medford-Park Falls District using daily air temperatures in the Norm81m data set (1981-2012) (PRISM Climate Group 2013). We know of no comparable large-scale datasets for pond water temperature. We used annual mean surface area and water depth to compare local precipitation conditions as reflected in the pond's hydrology. Regional precipitation patterns often do not adequately reflect how a pond's local hydrology may change because of the differences in geology, soils, and other factors (see Colburn, 2004).

We used a linear model with a Gaussian error structure to determine if there was a trend in peak salamander numbers across the years within a pond. Means have a Gaussian distribution by the Central Limit Theorem. To determine if there were any changes in timing of peak numbers/trap night, mean observed air temperature, mean observed water temperature, mean Medford-Park Falls District April temperature, and mean water depth and surface area over the study years, we used linear models with a Gaussian error structure. We categorized the years into decades: 1990s (1992-1994) and 2000s (2005-2007). We modeled the response as a function of decade, pond, and the interaction of pond and decade. We also modeled mean April temperature for the Medford-Park Falls District as a function of year (1981-2012) to put the study years into perspective. All analyses were done using the statistical package R (R Core Team, 2009) and significance was assesses at an alpha of 0.05 .

Because of the differences in trapping conditions in 1992 (e.g., number of traps, start of trapping due to late ice out) compared to the other years, we ran all the analyses with and without 1992. The conclusions from the test results were the same so we report the results including 1992.

\section{RESULTS}

A. laterale numbers varied among the 4 woodland ponds (Table 1); Pond 23 had the fewest A. laterale (peak number mean $=0.6$ salamanders/trap night, $\mathrm{SE}=0.2, \mathrm{n}$ $=6$ ) and Pond 5 had the most (peak number mean = 1.6 salamanders/trap night, $\mathrm{SE}=0.4$ ), but numbers did not change over time in any of the ponds (Pond 18: $F=$ 2.28, $\mathrm{df}=1,4, \mathrm{P}=0.21$; Pond $5: \mathrm{F}=1.19$, $\mathrm{df}=1,4$, $\mathrm{P}=0.34$; Pond $23: \mathrm{F}=0.20, \mathrm{df}=1,4, \mathrm{P}=0.68$; Pond 2: $F=0.004, d f=1,4, P=0.95)$. While $A$. maculatum numbers were low, there was some variation among the ponds (Table 1); Pond 23 had the fewest $A$. maculatum ( peak number mean $=0.06$ salamanders/trap night, $\mathrm{SE}$ $=0.03, \mathrm{n}=6$ ) and Pond 18 had the most (peak number mean $=0.4$ salamanders $/$ trap night, $\mathrm{SE}=0.1$ ) (Table 1$)$. A. maculatum numbers within a pond also did not change 
over time (Pond 18: $F=1.79, \mathrm{df}=1,4, \mathrm{P}=0.25$; Pond 5: $F=2.91, \mathrm{df}=1,4, \mathrm{P}=0.16$; Pond 23: $\mathrm{F}=0.43$, df $=1,4, P=0.55$; Pond $2: F=1.68, \mathrm{df}=1,4, \mathrm{P}=0.26)$. Overall, more $A$. laterale were found in the ponds than $A$. maculatum (mean difference of $A$. laterale minus $A$. maculatum $=0.65$; paired-t $=7.7, \mathrm{df}=23, \mathrm{P}<0.001$ )

Vegetation composition within $300 \mathrm{~m}$ of the ponds did not change between the decades for Ponds 18 and 2 (Table 2). Both ponds had low proportions of open forest conditions, but did have higher proportions of open shrub (Pond 18) and nonforest (Pond 2) than the other woodland ponds. In Ponds 5 and 23, the decadal changes reflected forest management activities. The landscape around Pond 5 became more open from an increase in even-aged harvests between the decades (Table 2). Proportion of regenerating canopy conditions increased from 0.12 to 0.52 , indicating that over half of the surrounding vegetation for this pond went from closed to open canopy conditions. The landscape around Pond 23 had an increase in regenerating upland conifer and a maturation of upland deciduous trees (Table 2 ), resulting in no discernible change in open canopy conditions.

The timing of peak salamander numbers changed between the decades for both salamander species $(A$. laterale: $F=37.3, \mathrm{df}=1,19, \mathrm{P}<0.001 ; A$. maculatum: $\mathrm{F}$ $=13.4, \mathrm{df}=1,12, \mathrm{P}=0.003)$, regardless of pond $(A$. laterale: $F=0.72, d f=3,19, P=0.55 ; A$. maculatum: $\mathrm{F}=0.70, \mathrm{df}=2,12, \mathrm{P}=0.52$ ). Overall, peak numbers of A. laterale occurred 11.7 days earlier (range: 9 - 14 days) in the 2000s compared to the 1990s (Table 3). Peak numbers of $A$. maculatum occurred 9.5 days earlier (range: 3 - 13 days) in the 2000s for the three ephemeral ponds (Table 3).
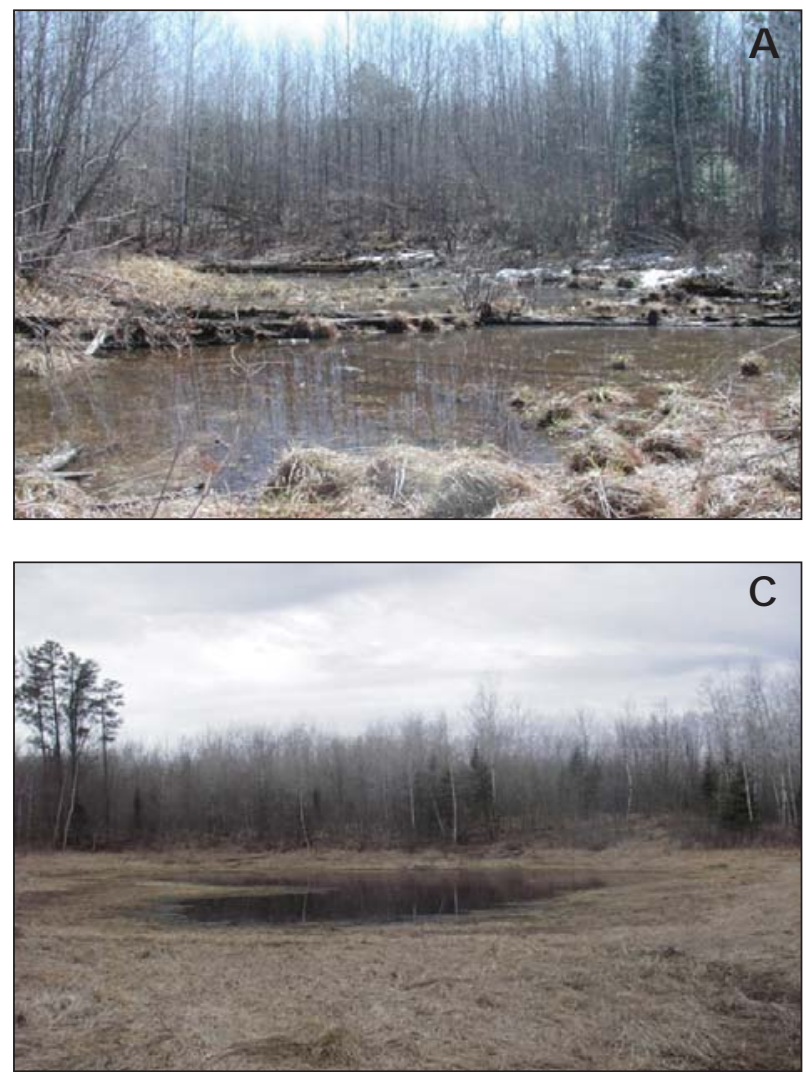

Mean observed air temperature (April 13-24) at the ponds increased, on average, $4.8^{\circ} \mathrm{C}$ between the study years $(F=18.91$, $d f=1,16, P<0.001)$ (Table 3$)$, regardless of pond $(\mathrm{F}=0.34, \mathrm{df}=3,16, \mathrm{P}>0.50)$ (Figure 3). Medford-Park Falls District April 13-24 mean temperatures also increased across the study years (1992-1994: mean $=4.2^{\circ} \mathrm{C}, \mathrm{SE}=1.3^{\circ} \mathrm{C} ; 2005-2007:$ mean $=8.9^{\circ} \mathrm{C}$ $\left.\mathrm{SE}=0.8^{\circ} \mathrm{C}\right)(\mathrm{F}=9.9, \mathrm{df}=1.4, \mathrm{P}=0.03)$. However, over 1981-2012, the Medford-Park Falls District April 13-24 mean temperature was stable at $5.6{ }^{\circ} \mathrm{C}(\mathrm{F}=1.2$, df $=$ $1, P=0.28$ ) (Figure 3 ). Water temperatures during the common trapping period also increased, on average, 3.7 ${ }^{\circ} \mathrm{C}$ (range: $2.2-5.5^{\circ} \mathrm{C}$ ) between the study years $(\mathrm{F}=$ $56.4, \mathrm{df}=1,16, \mathrm{P}<0.0001)$, regardless of pond $(\mathrm{F}=$ $1.9, \mathrm{df}=3,16, \mathrm{P}=0.18$ ), though ponds varied in their individual water temperatures (Pond term: $F=4.2, \mathrm{df}=$ 3, 16, $\mathrm{P}=0.02$ ) (Table 3).

Mean pond surface area and water depth did not change across years for Pond 18 (surface area: $F=0.06$, df $=1$, $4, \mathrm{P}=0.81$; water depth: $\mathrm{F}=1.01, \mathrm{df}=1,4, \mathrm{P}=0.91$ ) or Pond 5 (surface area: $F=1.3, \mathrm{df}=1,4, \mathrm{P}=0.31$; water depth: $F=0.65, d f=1,4, P=0.46)$. Pond 18 had a mean surface area of $401.7 \mathrm{~m}^{2}\left(\mathrm{SE}=107.3 \mathrm{~m}^{2}\right)$ and mean water depth of $0.27 \mathrm{~m}(\mathrm{SE}=0.07 \mathrm{~m})$ while Pond 5 had a mean surface area of $678.5 \mathrm{~m}^{2}(\mathrm{SE}=31.9 \mathrm{~m} 2)$ and mean water depth of $0.23 \mathrm{~m}(\mathrm{SE}=0.01 \mathrm{~m}$ ) (Table 1 ). Pond surface area and water depth decreased over time for Pond 2 (surface area: slope $=-35.25, F=14.85$, $\mathrm{df}=1,4, \mathrm{P}=0.02$; water depth: slope $=-0.02, \mathrm{~F}=$ 19.47, $\mathrm{df}=1,4, \mathrm{P}=0.01$ ), and Pond 23 (surface area: slope $=-115.07, F=12.37, \mathrm{df}=1,4, \mathrm{P}=0.02$; water depth: slope $=-0.03, \mathrm{~F}=8.14 \mathrm{df}=1,4, \mathrm{P}=0.05)$. In the 1990s, Pond 2 had a mean surface area of 1645.3
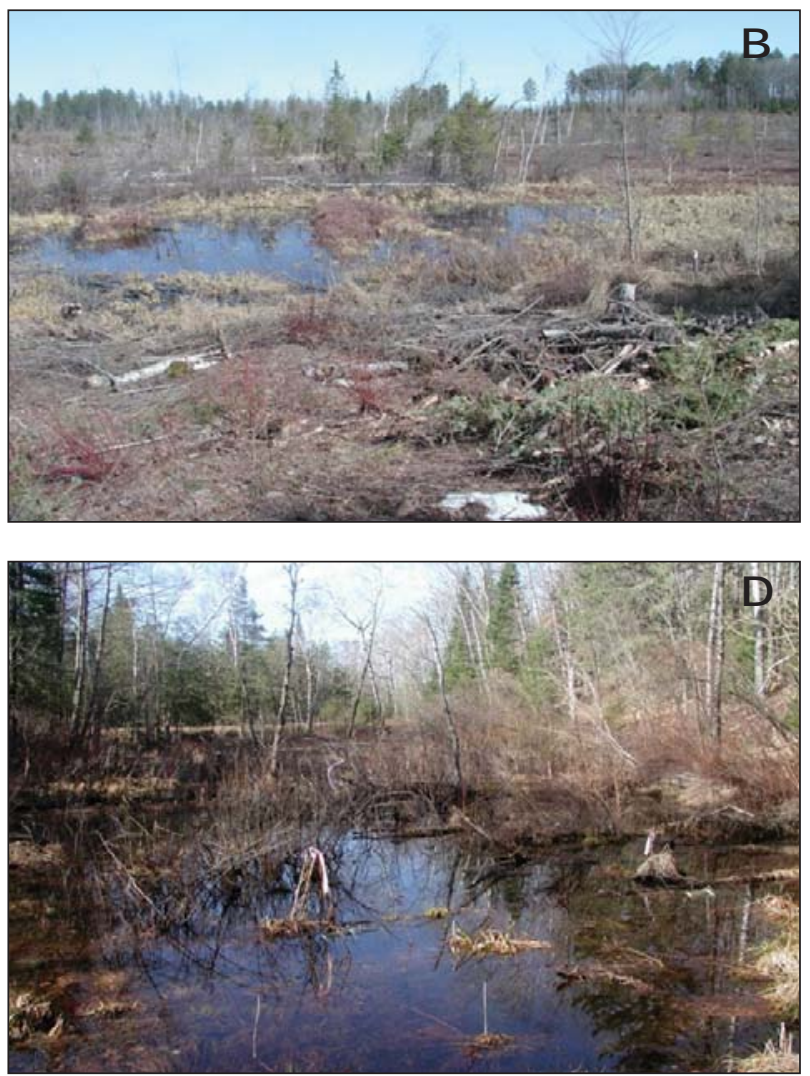

Figure 2. Of the four ponds, three are long-cycle, spring filling ponds: (A) Pond 18, predominantly open water, surface water and precipitation fed, (B) Pond 5, partially shaded to open, shallow sedge meadow, (C) Pond 23 , predominantly open water, groundwater fed, while Pond 2 (D) is semi-permanent neighboring a stream. 
$\mathrm{m}^{2}\left(\mathrm{SE}=10.7 \mathrm{~m}^{2}\right)$ and water depth of $0.63 \mathrm{~m}(\mathrm{SE}=0.01$ $\mathrm{m})$ while in the 2000s, mean surface area was 1168.7 $\mathrm{m}^{2}\left(\mathrm{SE}=102.7 \mathrm{~m}^{2}\right)$ and water depth was $0.34 \mathrm{~m}(\mathrm{SE}=$ $0.06 \mathrm{~m}$ ) (Table 1 ). In the 1990s, Pond 23 had a mean surface area of $3380.0 \mathrm{~m}^{2}\left(\mathrm{SE}=401.5 \mathrm{~m}^{2}\right)$ and water depth of $0.70 \mathrm{~m}(\mathrm{SE}=0.13 \mathrm{~m})$ while in the $2000 \mathrm{~s}$, mean surface area was $1982.0 \mathrm{~m}^{2}\left(\mathrm{SE}=320.0 \mathrm{~m}^{2}\right)$ and water depth was $0.38 \mathrm{~m}(\mathrm{SE}=0.06 \mathrm{~m}$ ) (Table 1$)$. There was no relationship between peak numbers of salamanders and surface area or water depth across years within the same pond (surface area; $A$. laterale: Pond 18: $F=0.57, \mathrm{df}=$ $1,4, P=0.49$; Pond 5: $F=0.17$, df $=1,4, P=0.90$; Pond 23: $F=1.81$, df $=1,4, P=0.25$; Pond 2: $F=0.09$, $\mathrm{df}=1,4, \mathrm{P}=0.77 ; \mathrm{A}$. maculatum: Pond 18: $\mathrm{F}=0.56 \mathrm{df}$ $=1,4, \mathrm{P}=0.49$; Pond $5: \mathrm{F}=0.31$, $\mathrm{df}=1,4, \mathrm{P}=0.61$; Pond 23: $F=1.32, \mathrm{df}=1,4, \mathrm{P}=0.31$; Pond 2: $\mathrm{F}=0.59$, $\mathrm{df}=1,4, \mathrm{P}=0.49$ ) (water depth; $A$. laterale: Pond 18: $\mathrm{F}$ $=0.58, \mathrm{df}=1,4, \mathrm{P}=0.49 ;$ Pond $5: \mathrm{F}=0.40, \mathrm{df}=1,4$, $\mathrm{P}=0.56$; Pond 23: $\mathrm{F}=3.32$, df $=1,4, \mathrm{P}=0.14$; Pond 2 : $\mathrm{F}=0.03, \mathrm{df}=1,4, \mathrm{P}=0.86 ; \mathrm{A}$. maculatum: Pond 18: $\mathrm{F}$ $=0.54, \mathrm{df}=1,4, \mathrm{P}=0.50 ;$ Pond $5: \mathrm{F}=0.98, \mathrm{df}=1,4$, $\mathrm{P}=0.38$; Pond 23: $\mathrm{F}=2.78, \mathrm{df}=1,4, \mathrm{P}=0.17$; Pond $2: F=0.69, d f=1,4, P=0.45)$.

\section{DISCUSSION}

Our major finding was the earlier shift by approximately 10-12 days in peak salamander numbers likely due to site-specific warmer air and water temperatures in 2005-2007. To our knowledge, the earlier shift in peak salamander numbers at breeding woodland ponds that we report here has not been documented previously for mole salamanders in the Upper Great Lakes region. Our results support other research showing earlier movement and reproductive effort in amphibian populations in response to changing environmental conditions (Carey and Alexander, 2003). Warming monthly temperatures prior to breeding activity has been attributed to a trend toward earlier breeding of several salamander populations in Japan (Kusano and Inoue, 2008), amphibian populations in southern England (Beebee, 1995; Reading, 1998), some

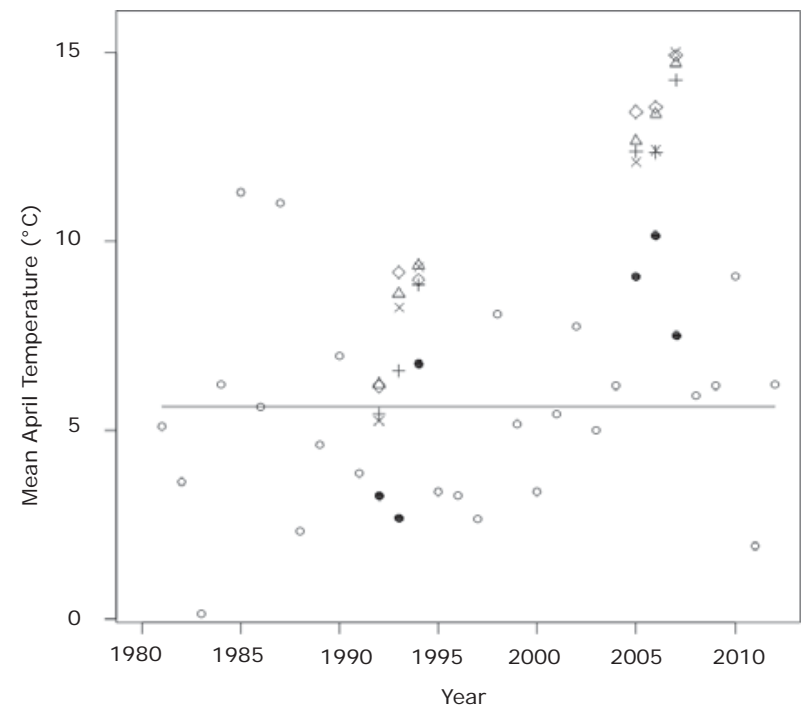

Figure 3. Mean April temperatures for April 13-24, 1981 - 2012 for the Medford-Park Falls District of the Chequamegon-Nicolet National Forest based on PRSIM data (PRISM Climate Group, Oregon State University, http://prism. oregonstate.edu, created 2 J uly 2014). The solid line is the regional mean air temperature for 1981-2012. Solid circles indicate regional mean values for sampled years and the triangle (Pond 18), X (Pond 5), + (Pond 2), and diamond (Pond 23) indicate mean values from air temperatures measured at the four ponds. amphibian species in Oregon and New York (Blaustein et al., 2001; Gibbs and Breisch, 2002), and ten amphibian species in South Carolina (Todd et al., 2011).

The earlier timing in peak salamander numbers in our study occurred across all ponds regardless of hydrologic condition and surrounding changes in vegetation canopy cover. Only Ponds 23 and 2 showed decreased water surface area and depth across decades. Potential reasons for this decline may be exposure to water sources other than precipitation and surface water. Pond 23 is exposed to groundwater, so it may take more time to recover following dry conditions, and Pond 2 is a semi-permanent pond that may not have received water from the nearby stream during dry conditions. Regional precipitation has been declining in northern Wisconsin (1950-2006 time period, WICCl 2011), which may explain decreased water levels in the groundwater and neighboring streams for these two ponds. Except for Pond 5, there were no discernible changes in canopy openness beyond the 'no harvest' buffer $(30 \mathrm{~m})$ in surrounding forest type classes between decades that would have warmed the water sooner (i.e., more light penetration). For Pond 5, there was an increase in canopy openness beyond the 'no harvest' buffer as a result of two harvests that occurred in 1995 and 1997. However, by 2005, succession would have diminished the open canopy effects (i.e., provided some shade). In addition, this change in surrounding openness would not influence canopy cover over the pond due to the 'no harvest' management buffer distance. Thus, we were better able to link salamander activity events to temperature changes, and not vegetation changes due to management around these 4 ponds or local precipitation patterns as reflected in pond water depth.

Our finding that salamander abundance did not change between the decades, but varied across years was expected due to annual variation in precipitation and temperature, which drive major amphibian life-cycle events. This pattern existed regardless of pond hydrologic condition and vegetative cover in the landscape. The dominance of $A$. laterale over $A$. maculatum is most likely indicative of $\mathrm{A}$. laterale being the most abundant and widely distributed salamander in Wisconsin (Casper, 1996). In addition, A. laterale may be more tolerant of habitat disturbance than A. maculatum, and will occupy coniferous forests and open fields, unlike A. maculatum (Harding, 2000).

Though our study was an observational study that serendipitously found a possible influence of climate change, our findings contribute to growing evidence from around the world that amphibian populations have responded to changing climate conditions by shifting life-cycle events. In northwest Wisconsin, average spring temperatures have increased by $3.5{ }^{\circ} \mathrm{C}$ and the date of last spring freeze has occurred earlier by two weeks (1950-2006 time period, WICCI 2011). Our study, then, took place at the warm end of the time trend but there were still varying conditions to which the salamanders responded. Thus, we were able to quantify the ability of salamanders to respond to changing environmental conditions. In Wisconsin, spring precipitation state-wide is expected to increase and occur more frequently as intense events that will increase the number of high water events, which will influence hydroperiod (specifically timing and duration of flooding). In response, we expect breeding salamander numbers will continue to peak earlier in the area's woodland ponds. In addition, summer temperatures regardless of region are expected to increase, which will increase evapotranspiration $(\mathrm{WICCl}, 2011)$ and may 
shorten the duration of flooding and thus, the timing of emigration of juveniles as well.

Of note is that our temperature and precipitation (via water level) data were measured at the pond-site during sampling rather than monthly averages retrieved from a local weather station as many phenology studies use (e.g., Beebee, 1995; Reading, 1998; Gibbs and Breisch, 2002). Being aware of how salamander activity patterns vary with local vegetation conditions as well as local environmental conditions will help managers plan forest management activities in the surrounding landscapes to avoid vulnerable movement periods of amphibians, and plan monitoring activities to adequately evaluate condition of woodland pond habitat and impacts of surrounding forest management.

Recent research trends have been investigating the indirect threats on amphibian populations, but direct effects such as habitat change (e.g., loss) continue to be pressing issues (Gardner et al., 2009; Hof et al., 2011). We argue that if possible, monitoring activities should be designed to incorporate both types of threats to better conserve these species. In addition, studies need to investigate processes affected by early breeding (Paton and Crouch, 2002; Carey and Alexander, 2003; Visser and Both, 2005), and designed using a multi-scale approach that incorporates local site variation, gradients in pond hydrology and hydroperiod, time-since-disturbance, and temperature and precipitation trends across long time periods. To better understand and address the combined effects of changing environmental conditions and forest management on woodland pond salamanders.

\section{ACKNOWLEDGEMENTS}

Field work for this project was carried out by the US Forest Service Chequamegon-Nicolet National Forest and data analysis was done as part of a Research Joint Venture with the Department of Forest and Wildlife Ecology, University of Wisconsin-Madison. We thank H. Stricker, L. Berkman, G. Smith, and two anonymous reviewers for comments on previous drafts of the manuscript. Mention of trade names does not constitute endorsement for use by the U.S. government.

\section{LITERATURE CITED}

Adams, M.J., Miller, D.A.W., Muths, E., Corn, P.S., Grant, E.H.C., Bailey, L.L., Fellers, G.M., Fisher, R.N., Sadinski, W.J., Waddle, H., and S.C. Walls. 2013. Trends in mphibian Occupancy in the United States. PLoS ONE 8: (5): e64347. doi: 10.1371/journal. pone.0064347

Alwegg, R. 2002. Predator-induced life-history plasticity under time constraints in pool frogs. Ecology 83:2542-2551

Baldauf, R.J. 1952. Climatic factors influencing the breeding migration of the $\mathrm{A}$. maculatum, Ambystoma maculatum (Shaw). Copeia 1952(3): 178-181.

Baldwin, R.F., A.J.K. Calhoun, and P.G. deMaynadier. 2006. The significance of hydroperiod and stand maturity for pool-breeding amphibians in forested landscapes. Canadian J ournal of Zoology 84: 1604-1615.

Beebee, T. 1995. Amphibian breeding and climate. Nature 374:219-220.

Blaustein, A.R., L.K. Belden, D.H. Olson, D.M. Green, T.L. Root, and J.M. Kiesecker. 2001. Amphibian breeding and climate change. Conservation Biology 15: 18041809.

Brooks, R.T. 2004. Weather-related effects on woodland vernal pool hydrology and hydroperiod. Wetlands 24: 104-114.
Brooks, R.T. 2009. Potential impacts of global climate change on the hydrology and ecology of ephemeral freshwater systems of the forests of the northeastern United States. Climatic Change 95:469-483.

Brooks, R.T. and M.H. Hayashi. 2002. Depth-area-volume and hydroperiod relationships of ephemeral (vernal) forest pools in southern New England. Wetlands 22:247-255.

Burn, M.R. and C.R. Griffin. 2005. Habitat associations of pool-breeding amphibians in eastern Massachusetts, USA. Wetlands Ecology and Management 13:247259.

Carey, C., and M.A. Alexander. 2003. Climate change and amphibian declines: is there a link? Diversity and Distributions 9: 111-121.

Casper, G.S. 1996. Geographic Distributions of the Amphibians and Reptiles of Wisconsin. Milwaukee Public Museum, Milwaukee, WI. 87 pp.

Colburn E. A. 2004. Vernal Pools: Natural History and Conservation. The McDonald \& Woodward Publishing Company, Blacksburg, VA. 426 p.

deMaynadier, P.G., and M.L. Hunter, Jr. 1995. The relationship between forest management and amphibian ecology: a review of the North American literature. Environmental Reviews 3:230-261.

deMaynadier, P.G., and M.L. Hunter. 1998. Effects of silvicultural edges on the distribution and abundance of amphibians in Maine. Conservation Biology 12:340352.

Egan, R.S., and P.W.C. Paton. 2004. Within-pond parameters affecting oviposition by wood frogs and $A$. maculatum. Wetlands 24:1-13.

Faccio, S.D. 2003. Postbreeding emigration and habitat use by Jefferson and A. maculatum in Vermont. J ournal of Herpetology 37(3):479-489.

Foden, W B., S.H.M. Butchart, S.N. Stuart, J. Vié, H.R. Akçakaya, et al. 2013. Identifying the world's most climate change vulnerable species: a systematic trait-based assessment of all birds, amphibians and corals. PLoS ONE 8: e65427.

Gardner, T.A., J. Barlow, and C.A. Peres. 2007. Paradox, presumption and pitfalls in conservation biology: The importance of habitat change for amphibians and reptiles. Biological Conservation 138: 166-179.

Gibbs, J. P. 1998. Distribution of woodland amphibians along a forest fragmentation gradient. Landscape Ecology 13:263-268.

Gibbs, J.P, and A.R. Breisch. 2002. Climate warming and calling phenology of frogs near Ithaca, NY, 19001999. Conservation Biology 15:1175-1178.

Harding, J.H. 2000. Amphibians and Reptiles of the Great Lakes Region. The University of Michigan Press, Ann Arbor, MI. 378 p.

Hocking, D.J., T.A. Rittenhouse, B.B. Rothermel, J.R. Johnson, C.A. Conner, E.B. Harper, and R.D. Semlitsch. 2008. Breeding and recruitment phenology of amphibians in Missouri oak-hickory forests. The American Midland Naturalist 160:41-60.

Hof, C., M. B. Ara' ujo, W. Jetz, and C. Rahbek. 2011. Additive threats from pathogens, climate and landuse change for global amphibian diversity. Nature 480: 516-519.

Holaday, S., and C. Wagner. 2010. Wisconsin's forestry best management practices for water quality: field manual. Wisconsin Department of Natural Resources, Publication FR-093. 82 pp.

Homan, R.N., B.S. Windmiller, and J.M. Reed. 2004. Critical thresholds associated with habitat loss for two 
vernal pool-breeding amphibians. Ecological Applications 14: 1547-1553.

Houlahan, J.E., C.S. Findlay, B.R. Schmidt, A.H. Meyer, and S.L. Kuzmin. 2000. Quantitative evidence for global amphibian population declines. Nature 404: 752-755.

Kusano, T. and M. Inoue. 2008. Long-term trends toward earlier breeding of Japanese amphibians. Journal of Herpetology 42:608-614.

Madison, D.M. 1997. The emigration of radio-implanted A. maculatum, Ambystoma maculatum. Journal of Herpetology 31:542-551.

Meyer ,A.H., Schmidt, B.R., and Grossenbacher, K. 1998. Analysis of three amphibian populations with quarter-century long time-series. Proc. R. Soc. Lond. B 265: 523-528.

Morris, K.M. and T.J. Maret. 2007. Effects of timber management on pond-breeding salamanders. The Journal of Wildlife Management 71:1034-1041.

Paton, P.W.C., and W.B.J. Crouch. 2002. Using the phenology of pond-breeding amphibians to develop conservation strategies. Conservation Biology 16:194204.

Patrick D.A., M.L. Hunger, J r., and A.J.K. Calhoun. 2006. Effects of experimental forestry treatments on a Maine amphibian community. Forest Ecology and Management 234:323-332.

Pechmann, J.H.K., D.E. Scott, J.W., Gibbons, and R.D. Semlitsch. 1989. Influence of wetland hydroperiod on diversity and abundance of metamorphosing juvenile amphibians. Wetland Ecology and Management 1:3-11.

Petranka, J.W. 1998. Salamanders of the United States and Canada. Smithsonian Institution Press, Washington, D.C., USA. 592 p.

PRISM Climate Group. 2013. Descriptions of PRISM spatial climate datasets for the conterminous United States. http://prism.nacse.org/documents/PRISM_ datasets_aug2013.pdf (accessed July 2014)

R Development Core Team, 2009. R: A language and environment for statistical computing, version 2.9.0. R Foundation for Statistical Computing, Vienna, Austria. (ISBN 3-900051-07-0). http://www. R-project. org (accessed December 2009)

Reading, C.J. 1998. The effect of winter temperatures on the timing of breeding activity in the common toad Bufo bufo. Oecologia 117:469-475.

Regosin, J.V., B.S. Windmiller, R.N. Homan, and J.M. Reed. 2005. Variation in terrestrial habitat use by four pool-breeding amphibian species. Journal of Wildlife Management 69:1481-1493.

Relyea, R.A. 2003. How prey respond to combined predators: a review and empirical test. Ecology 84: 18271839.

Rittenhouse, T.A.G., R.D. Semlitsch, and F.R. Thompson III. 2009. Survival costs associated with wood frog breeding migrations: effects of timber harvest and drought. Ecology 90: 1620-1630.Semlitsch, R.D. 1998. Biological delineation of terrestrial buffer zones for pond-breeding salamanders. Conservation Biology 12:1113-1119.
Semlitsch, R.D. 2002. Critical elements for biologically based recovery plans of aquatic-breeding amphibians. Conservation Biology 16:619-629.

Semlitsch, R.D., and J.R. Bodie. 2003. Biological criteria for buffer zones around wetlands and riparian habitats for amphibians and reptiles. Conservation Biology 17: 1219-1228.

Semlitsch, R.D., B.D. Todd, S.M. Blomquist, A.J.K. Calhoun, J.W. Gibbons, J.P. Gibbs, G.J. Graeter, E.G. Harper, D.J. Hocking, M.L. Hunter, J r., D.A. Patrick, T.A.G. Rittenhouse, and B.B. Rothermel. 2009. Effects of timber harvest on amphibian populations: understanding mechanisms from forest experiments. BioScience 59: 853-862.

Sexton, O.J., C. Phillips, and J. E. Bramble. 1990. Effects of temperature and precipitation on the breeding migration of the A. maculatum (Ambystoma maculatum). Copeia 1990: 781-787.

Skidds, D.E. and F.C. Golet. 2005. Estimating hydroperiod suitability for breeding amphbians in southern Rhode Island seasonal forest ponds. Wetland Ecology and Management 13:349-366.

Stebbins, R.C. and N. W. Cohen. 1995. A Natural History of Amphibians. Princeton University Press, Princeton, New Jersey. 316 p.

Timm, B.C., K. McGarigal, and B.W. Compton. 2007. Timing of large movement events of pond-breeding amphibians in Western Massachusetts, USA. Biological Conservation 136: 442-454.

Todd, B.D., D.E. Scott, J.H.K. Pechmann, and J.W. Gibbons. 2011. Climate change correlates with rapid delays and advancements in reproductive timing in an amphibian community. Proceedings of the Royal Society B: Biological Sciences 278:2191-2197.

Trumbo D.R., A.A. Burgett, R.L. Hopkins, E.G. Biro, J.M. Chase, and J.H. Knouft. 2012. Integrating local breeding pond, landcover, and climate factors in predicting amphibian distributions. Landscape Ecology 27: 1183-1196.

Van Buskirk, J. 2005. Local and landscape influence on amphibian occurrence and abundance. Ecology 86: 1936-1947.

Veysey, J.S., S. D. Mattfeldt, and K.J. Babbitt. 2011. Comparative influence of isolation, landscape, and wetland characteristics on egg-mass abundance of two pool-breeding amphibian species. Landscape Ecology 26:661-672.

Visser, M.E., and C. Both. 2005. Shifts in phenology due to global climate change: the need for a yardstick. Proceedings of The Royal Society: B 22:2561-2569.

Wilson, C.R., and P.B. Pearman. 2000. Sampling characteristics of aquatic funnel traps for monitoring populations of adult rough-skinned newts (Taricha granulosa) in lentic habitats. Northwestern Naturalist $81: 31-34$.

Wisconsin Initiative on Climate Change Impacts [WIC$\mathrm{Cl}$ ]. 2011. Wisconsin's changing climate: impacts and adaptation. Nelson Institute for Environmental Studies and Wisconsin Department of Natural Resources, Madison, Wisconsin. http://www.wicci. wisc.edu/publications. php (accessed J uly 2014). 